\title{
POLA SEBARAN SPASIAL BIOMASSA DI AREAL REVEGETASI BEKAS TAMBANG NIKEL
}

\section{(Spatial Distribution Patterns of Biomass in Nickel Post-Mining Revegetation Area)}

\author{
Witno ${ }^{1}$ Nining Puspaningsih ${ }^{2}$ Budi Kuncahyo ${ }^{3}$ \\ ${ }^{1)}$ Staf Pengajar Fakultas Kehutanan Universitas Andi Djemma Palopo,Jl. Agro Kompleks Non \\ Blok, Palopo 1921 \\ ${ }^{2,3}$ ) Departemen Manajemen Hutan Fakultas Kehutanan Institut Pertanian Bogor, Jl. Lingkar \\ Akademik Kampus IPB Dramaga Bogor 16680 \\ Email: witnosanganna@gmail.com
}

\begin{abstract}
The aim of this study was to identify the spatial pattern of biomass distribution in the revegetation of the post-mining area in PTVI. The nearest neighbour analysis method by comparing the distance of an individual was used to determine the spatial biomass distribution pattern in the post nickel mining revegetation area of PTVI. The nearest neighbour analysis was used to explain the distribution pattern of locations using a calculation that considers the distance, number of locations and acreage. This analysis produced a final result in the form of an index ranging from 0 until more than 1. It can be explained as NNI $<1$, clustered spatial pattern, $N N I=1$, random spatial pattern and NNI> 1 dispersed spatial pattern. This research was found that there are clustered $(K 1, K 2, K 3)$ and dispersed patterns (K4) of biomass spatial distribution patterns in PTVI's post nickel mining revegetation area.
\end{abstract}

Keywords: post-mining, revegetation, biomass, spatial distribution pattern.

\begin{abstract}
Tujuan penelitian ini adalah mengidentifikasi pola sebaran spasial biomassa di areal revegetasi bekas tambang nikel PTVI. Metode yang digunakan dalam menentukan pola sebaran spasial biomassa di areal revegetasi bekas tambang nikel yaitu metode nearest neighbor analysis dengan membandingkan jarak dari suatu individu. Nearest neighbor analysis merupakan salah satu analisis yang digunakan untuk menjelaskan pola persebaran dari titik-titik lokasi dengan menggunakan perhitungan yang mempertimbangkan jarak, jumlah titik lokasi dan luas wilayah. Analisis ini memiliki hasil akhir berupa indeks, dimana indeks yang dihasilkan memiliki hasil antara 0 sampai lebih dari 1 dengan NNI $<1$ maka pola spasial yang terbentuk adalah clustered, NNI = 1 maka pola spasial yang terbentuk adalah random, NNI $>1$ maka pola spasial yang terbentuk adalah dispered. Sehingga hasil penelitian ini mendapatkan pola sebaran spasial biomassa di areal revegetasi bekas tambang ada dua yaitu pola mengelompok (Clustered) pada biomassa K1,K2, K3 dan pola menyebar (Dispersed) pada biomassa K4.

Kata kunci: Bekas tambang, Revegetasi, Biomassa, Pola Sebaran Spasial.
\end{abstract}




\section{PENDAHULUAN}

Pola sebaran spasial sangat membantu dalam mengambil keputusan tentang metode apa yang akan digunakan untuk mengestimasi kepadatan atau kelimpahan suatu populasi (Krebs 1998). Pola sebaran spasial adalah metode untuk mengetahui apakah penyebaran spesies pada satu wilayah tertentu menyebar secara acak (random), berkelompok (cluster) atau seragam (uniform) (Ludwig dan Reynold 1988). Lomolino et al. (2010), menjelaskan pola distribusi spasial merupakan respon organisme terhadap variasi lingkungan biofisik. Pola penyebaran spasial biomassa pada ekosistem hutan alam berbeda dengan pola penyebaran spasial pada ekosistem hutan tanaman. Lebih lanjut, Rani (2003), dalam suatu populasi memiliki perbedaan yang nyata dalam pola sebaran, meskipun memiliki kepadatan populasi yang sama. Umumnya pada beberapa penelitian, pola sebaran spasial biomassa hutan alam cenderung mengelompok. Pola mengelompok menunjukkan adanya kondisi fisik di lapangan yang heterogen, sehingga individu tumbuhan akan tumbuh mengelompok sesuai dengan kebutuhan hidupnya.

PT Vale Indonesia (PTVI) merupakan salah satu perusahan tambang nikel yang telah melakukan kegiatan revegetasi sejak tahun 1980 an. Total lahan yang telah direvegetasi hingga akhir tahun 2017 mencapai luas 3953.24 ha $(71.76 \%)$ dari 5508.13 ha total lahan tambang yang telah terbuka. Keberhasilan revegetasi dapat dinilai salah satunya dengan produktivitas hutan. Salah satu indikator penentu produktivitas hutan adalah biomassa (Hilmi 2003). Sehubungan dengan itu, keberhasilan revegetasi sangat berkorelasi dengan jumlah kandungan biomassa. Menurut Claassen et al. (2008) salah satu indikator keberhasilan reklamasi adalah adanya vegetasi. Pengetahuan tentang pola sebaran spasial biomassa diareal revegetasi bekas tambang sangat penting untuk diketahui. Khususnya, dalam membantu mengambil keputusan tentang metode apa yang akan digunakan untuk mengestimasi kepadatan atau kelimpahan suatu populasi (tanaman revegetasi) (Krebs 1989). Dalam hal ini pola sebaran spasial biomassa bermanfaat untuk perencanaan pengelolaan tanaman revegetasi bekas tambang dan bahan evaluasi untuk perencanaan monitoring dan penyelamatan kawasan perlindungan yang masuk dalam areal pertambangan. Berdasarkan kondisi ini, maka tujuan penelitian ini adalah megidentifikasi pola sebaran spasial biomassa di areal revegetasi bekas tambang PTVI. Penelitian ini sangat bermanfaat sebagai bahan evaluasi untuk perencanaan monitoring dan penyelamatan kawasan perlindungan yang masuk dalam areal pertambangan.

\section{METODOLOGI PENELITIAN}

Penelitian ini dilaksanakan di areal revegetasi bekas tambang nikel PTVI Kabupaten Luwu Timur, Propinsi Sulawesi Selatan. Pengambilan data dilakukan pada bulan Mei 2019. Alat dan bahan yang digunakan dalam penelitian software Arc-Gis 10.4, Minitab 17, Erdas 2014, kamera digital dan Citra SPOT 6 tahun 2017. Dua sumber data yang digunakan pada penelitian ini yaitu data primer dan data sekunder. Data primer adalah citra multispektral SPOT 6 yang memiliki resolusi spasial 6 meter dan 1.5 meter untuk pankromatik, koordinat sample plot dan nama jenis pohon. Data sekunder diperoleh melalui studi literatur, seperti jurnal, buku, data base, dan peta kerja.

Pengolahan peta sebaran spasial biomassa menggunakan model penduga biomassa. Model penduga biomassa yang digunakan dalam membangun peta sebaran spasial biomassa adalah bentuk persamaan $\mathrm{Y}=$ 2.59505E-13 $\mathrm{X}_{1}{ }^{2.489} \mathrm{X}_{2}{ }^{3.645}$ (Witno et al. 2018). Variabel $X_{1}$ merupakan nilai Indeks 
Volume 1 Nomor 2 Des 2019:1-9

vegetasi DVI (Difference Vegetation Index) dan $\mathrm{X}_{2}=\mathrm{C} \%$ (persentase tajuk) yang didapatkan dari citra SPOT 6 2017. Bentuk persamaan ini merupakan hasil pendugaan biomassa yang dilakukan di areal revegetasi bekas tambang nikel PTVI. Pengolahan peta sebaran spasial biomassa dengan menggunakan Arcgis 10.4. Pola sebaran spasial biomassa dianalisis berdasarkan pada setiap kelas biomassa yaitu dari kelas biomassa rendah sampai kelas biomassa tinggi. Tujuan pengkelasan untuk memberikan gambaran informasi yang lebih detail.

Analisis data pola sebaran spasial dapat ditentukan tipe penyebarannya dengan menggunakan metode nearest neighbor analysis dengan membandingkan jarak dari suatu individu. Nearest neighbor analysis merupakan salah satu analisis yang digunakan untuk menjelaskan pola persebaran dari titiktitik lokasi tempat dengan menggunakan perhitungan yang mempertimbangkan jarak, jumlah titik lokasi dan luas wilayah. Analisis ini memiliki hasil akhir berupa indeks, yang memiliki hasil antara 0 sampai lebih dari 1. Nilai 0 menunjukkan bahwa polanya cenderung memiliki tipe mengelompok (cluster),jika nilainya 1(berada di tengah) memiliki pola acak (random), sedangkan lebih dari 1 memiliki tipe pola seragam (uniform) (Ludwig dan Reynold 1988). Ringkasnya dapat dilihat pada formula berikut:

NNI < 1 maka pola spasial yang terbentuk adalah clustered

NNI = 1 maka pola spasial yang terbentuk adalah random

NNI > 1 maka pola spasial yang terbentuk adalah dispered

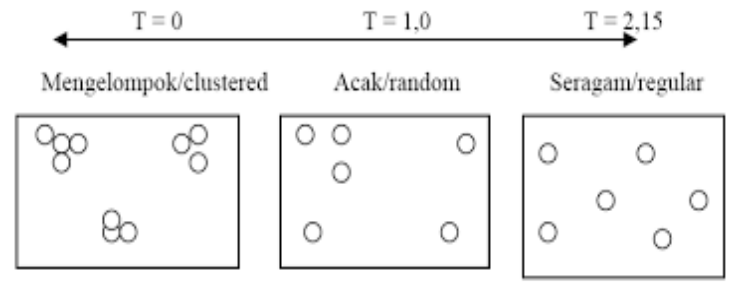

Gambar 1 Pola sebaran spasial
Secara umum metode dalam menentukan pola sebaran spasial biomassa dengan menggunakan Arcgis sebagai berikut:

1. Membuat centroid dari masing-masing poligon kelas biomassa yang merupakan titik pusat dari suatu cluster yang digunakan untuk menghitung jarak antar obyek.

2. Menggunakan euclidean distance method yaitu metode yang menggunakan panjang garis lurus yang menghubungkan masingmasing objek yang merupakan jarak terpendek antara masing-masing obyek.

3. Metode nearest neighbor analysis dengan jarak euclidean distance menghasilkan nilai Observed Distance (DO), Expected Distance (DE), dan Nearest Neighbor Index (NNI). Observed Distance merupakan jarak rata-rata antar objek yang diamati sedangkan Expected Distance merupakan jarak rata-rata ekspektasi, yaitu jarak rata-rata antara tetangga dalam distribusi acak hipotesis.NNIdinyatakan sebagai rasio antara jarak rata-rata antar objek yang diamati dibagi dengan jarak ekspektasi rata-rata antara tetangga dalam distribusi acak hipotesis. Hasil NNI menunjukkan jarak rata-rata observasi dan ekspektasi antara titik satu dengan fitur terdekatnya serta nilai Z-scorenya.

Secara matematis, nilai DO, DE, dan NNI dapat diformulasikan dengan rumus sebagai berikut:

$D O=\frac{\sum_{i=1}^{n} d i}{N}$,

$N N I=\frac{D O}{D E}$

$D E=\frac{0.5}{\sqrt{\frac{N}{A}}}$,

Keterangan:

$\mathrm{DO}=$ Observed Distance

$\mathrm{DE}=$ Expected Distance

$\mathrm{NNI}=$ Nearest Neighbor Index

$\mathrm{di}=$ jarak antar objek

$\mathrm{N}=$ jumlah individu

$\mathrm{A}=$ luas 
4. Analisis Z-score merupakan tes signifikasi statistik yang dapat menyimpulkan penerimaan atau penolakan hipotesis sebelumnya. Jika $|\mathrm{Z}|$ lebih rendah dari 1.96, sementara $\mathrm{H}_{0}$ diterima dengan $\alpha=$ 0.05 maka penyebaran dianggap secara acak di wilayah kajian (Krebs 2014). Formula nilai Z-score sebagai berikut:

Keterangan:

$$
S E=\frac{0.26}{\sqrt{\frac{N^{2}}{A}}}
$$

$\mathrm{SE}=$ tingkat kesalahan

$\mathrm{N}=$ jumlah individu

$\mathrm{A}=$ luas

Keterangan:

$$
Z S \text { core }=\frac{D O-D E}{S E}
$$

$Z<1.96:$ clustered

$Z>1.96:$ dispered

$Z=$ sebaran normal: random

$\mathrm{SE}=$ tingkat kesalahan

$\mathrm{DO}=$ Observed Distance

$\mathrm{DE}=$ Expected Distance

\section{HASIL DAN PEMBAHASAN}

\section{Sebaran Spasial Biomassa di Areal Revegetasi Bekas Tambang Nikel}

Kajian pola sebaran spasial biomassa di areal revegetasi bekas tambang masih sangat jarang dilakukan. Manfaat dari analisis spasial pola sebaran spasial biomassa di areal revegetasi bekas tambang PTVI, memudahkan untuk mengontrol kondisi tanaman revegetasi berdasarkan data biomassanya. Selain itu, dapat dijadikan sebagai acuan atau indikator dalam menilai keberhasilan revegetasi. Peraturan Pemerintah nomor 78 tahun 2010 tentang Reklamasi dan Pascatambang pasal 4 ayat 1 huruf (a) dan (f) tentang perlindungan kawasan hutan di areal konsesi tambang. Perlindungan yang dimaksud adalah perlindungan terhadap kualitas air permukaan, air tanah, air laut dan kuantitas air tanah. Keberhasilan revegetasi di aeral bekas tambang akan sangat mendukung sebagaimana yang dimaksud dalam peraturan pemerintah tentang perlindungan kawasan hutan di areal konsesi tambang. Untuk mendukung hal tersebut, maka pola sebaran spasial biomassa pada penelitian ini bisa membantu dalam memonitoring kawasan revegetasi. Pada penelitian ini, pola sebaran spasial biomassa dominan mengelompok didekat sumber air. Mengindikasikan bahwa biomassa bisa dipengaruhi oleh keberadaan sumber air yang erat kaitannya dengan tingkat kesuburan tanah maupun pertumbuhan tanaman. Kondisi ini memerlukan pengawasan dan monitoring terhadap areal-areal yang menjadi sumber air, baik terhadap tanaman revegetasi maupun sumber air masyarakat sekitar.

Model penduga biomassa yang digunakan dalam membangun peta sebaran spasial biomassa menggunakan bentuk persamaan $\mathrm{Y}=2.59505 \mathrm{E}-13 \quad \mathrm{X}_{1}{ }^{2.489} \mathrm{X}_{2}{ }^{3.645}$ (Witno et al.2018). Variabel $\mathrm{X}_{1}$ merupakan nilai Indeks vegetasi DVI (Difference Vegetation Index) dan $\mathrm{X}_{2}=\mathrm{C} \%$ (persentase tajuk) yang didapatkan dari citra SPOT 6 2017. Hasil analisis pola sebaran spasial biomassa di areal revegetasi bekas tambang PTVI diperoleh nilai DO, DE, NNI dan Zscore. Berdasarkan nilai NNI dan Z-score diketahui bahwa pola sebaran spasial biomassa di areal revegetasi bekas tambang PTVI, memiliki pola mengelompok (Clustered) dan menyebar (Dispered). Kelas biomassa (K1 sampai K3) diperoleh data sebaran biomassa dengan nilai NNI $<1$ begitu juga dengan nilai Z-score $<$ 1.96. Pola mengelompok (clustered) di areal revegetasi bekas tambang dipengaruhi oleh kondisi tempat tumbuh, jenis tanaman serta kondisi biofisik tanah.

Kondisi yang heterogen mengakibatkan pola penyebaran biomassa 
juga mengelompok karena sesuai dengan kebutuhan hidup tanaman revegetasi. Tingkat kesuburan pertumbuhan tanaman revegetasi berbeda-beda. Faktor kesuburan tanah berpengaruh pada pertumbuhan tanaman revegetasi yang sekaligus berpengaruh pada jumlah kandungan biomassa. Sehingga terdapat satu kelas biomassa yaitu K4 memiliki pola sebaran spasial biomassa menyebar (Dispersed). Dengan nilai NNI >1 juga pada nilai Z-score $>1.96$. Jumlah kandungan biomassa berada pada rentang 176.62 sampai 235.50 ton/ha pada kelas biomassa 4. Hasil perhitungan untuk mengetahui pola sebaran spasial biomassa pada areal revegetasi bekas tambang nikel PTVI disajikan pada Tabel 1.

Tabel 1 menunjukkan bahwa metode klasifikasi tetangga terdekat (Nearest Neighbor analysis) dan metode dengan jarak euclidean distance menghasilkan nilai Observed Distance (DO), Expected Distance (DE), dan Nearest Neighbor Index (NNI) yang berbeda-beda. Berdasarkan nilai DO, DE, NNI dan Z-score pola sebaran spasial biomassa dapat diketahui. Pada Tabel 1 menunjukkan kelas yang paling mendekati nilai observasi lapangan adalah K3. Nilai observasi sebesar 429.97m dari nilai ekspektasi sebesar 580.86 $\mathrm{m}$.

Tabel 1 Kelas biomassa di areal revegetasi bekas tambang nikel PTVI

\begin{tabular}{lllllll}
\hline $\begin{array}{l}\text { Kelas } \\
\text { biomassa }\end{array}$ & $\begin{array}{l}\text { Biomassa tegakan } \\
\text { (ton/ha) }\end{array}$ & DO $(\mathrm{m})$ & DE $(\mathrm{m})$ & NNI & Z-Score & Pola \\
\hline K1 & $\leq 58.87$ & 187.51 & 350.12 & 0.53 & -15.69 & Clustered \\
K2 & $58.87-117.75$ & 177.20 & 365.18 & 0.48 & -14.63 & Clustered \\
K3 & $117.75-176.62$ & 429.97 & 580.86 & 0.74 & -3.10 & Clustered \\
K4 & $176.62-235.50$ & 3299.90 & 470.49 & 7.01 & 19.92 & Dispersed \\
\hline
\end{tabular}

Hasil overlay antara peta jalan tambang, kelas umur dengan peta sebaran spasial biomassa menunjukkan bentuk sebaran yang berbeda-beda pada masing-masing kelasnya. Beberapa penelitian tentang sebaran spasial dipengaruhi oleh faktor ekologis maupun biofisik individu dari objek penelitian. Condit et al. (2000), mengevaluasi pola spasial individu pohon dengan menghitung jumlah pohon yang sama dalam satu lingkungannya. Menunjukkan bahwa sebaran individu pohon sangat dipengaruhi oleh kondisi di sekelilingnya. Pada penelitian ini, sebaran spasial biomassa K1 memiliki pola mengelompok (Clustered) dengan nilai Nearest Neighbor Index (NNI) sebesar $0.53<1$. K2 juga memiliki pola mengelompok (Clustered) dengan nilai NNI sebesar $0.48<1$ dan nilai Z-score sebesar $14.63<1.96$. Begitu juga dengan K3 memiliki nilai NNI sebesar $0.74<1$ dan nilai Z-score sebesar $-3.10<1.96$ sehingga tergolong dalam pola mengelompok. Berbeda dengan K4 memiliki pola menyebar (Dispersed) dengan nilai NNI sebesar $7.01>1$ dan nilai Zscoresebesar $19.92>1.96$. Luas areal sebaran spasial biomassa pada masing-masing kelas dapat dilihat pada Tabel 2. 
Tabel 2 Sebaran spasial biomassa di areal revegetasi bekas tambang nikel PTVI

\begin{tabular}{llllll}
\hline \multirow{2}{*}{ Umur tanaman } & \multicolumn{4}{l}{ Luas sebaran spasial biomassa (ha) } & Total luas \\
\cline { 2 - 5 } & K1 & K2 & K3 & K4 & (ha) \\
\hline $0-4$ & 141.07 & 0.82 & & & \\
$5-9$ & 174.79 & 89.50 & 6.85 & & \\
$10-14$ & 710.83 & 697.54 & 273.46 & 51.94 & \\
$15-18$ & 380.19 & 282.60 & 181.09 & 101.66 & \\
Total & 1406.88 & 1070.46 & 461.39 & 153.60 & $\mathbf{3 0 9 2 . 3 3}$ \\
\hline
\end{tabular}

Umur tanaman revegetasi pada rentang 0 sampai 4 tahun tidak ditemukan pada K3 dan K4. Hasil ini, karena nilai biomassa untuk K3 dan K4 berada pada kisaran umur 10 sampai 14 tahun. K3 dan K4 menunjukkan bahwa terdapat pengaruh umur pada tanaman revegetasi terhadap jumlah kandungan biomassa di areal revegetasi bekas tambang.

\section{Sebaran Spasial Biomassa K1}

Tabel 2 menunjukkan bahwa K1 memiliki areal penyebaran terluas dengan total areal sebesar 1406.88 ha. Jumlah kandungan biomassa pada K1 sebesar $\leq 58.87$ ton/ha (Tabel 1). Areal terluas tingkat kandungan biomassa pada K1 berada pada rentang umur 10-14 tahun seluas 710.83 ha. Hasil ini menilai bahwa, ada korelasi antara kondisi tempat tumbuh atau tingkat kesuburan tanah, stratifikasi tajuk, jenis tanaman, keberadaaan tumbuhan bawah dan umur terhadap jumlah kandungan biomassa. Beberapa jenis tanaman yang didapatkan dilapangan yaitu Aghatis (Aghatis dammara), Cemara (Casuarina nobilis), Sengon (Enterolobium cyclocarpum), Nantu merah (Palaquim), Jambu-jambu (Syzygium sp), Dara-dara dan Johar (Senna siamea). Jenis tanaman ini berumur antara 714 tahun. Terdapat di areal Anoa tahun tanam 2006, 2007, 2008, Debby 2004 dan Delaney 2010. Pola sebaran spasial K1, yang mengelompok bisa juga disebabkan oleh banyaknya jalan tambang di sepanjang areal revegetasi. Selain itu, tingkat kesuburan tanah juga menjadi faktor yang berperan dalam sebaran spasial biomassa di areal revegetasi bekas tambang.

Pola mengelompok pada suatu populasi dipengaruhi oleh adanya faktor pembatas terhadap keberadaan suatu populasi. Lebih lanjut, Rani (2003), pengelompokan menunjukkan bahwa individu-individu berkumpul pada beberapa habitat yang menguntungkan. Dalam hal ini, biomassa mengelompok pada areal-areal yang disebabkan oleh faktor lingkungan yang heterogen, kondisi tempat tumbuh/kesuburan tanah, jenis tanaman dan umur. Pola sebaran spasial biomassa K1 dapat dilihat pada Gambar 2.

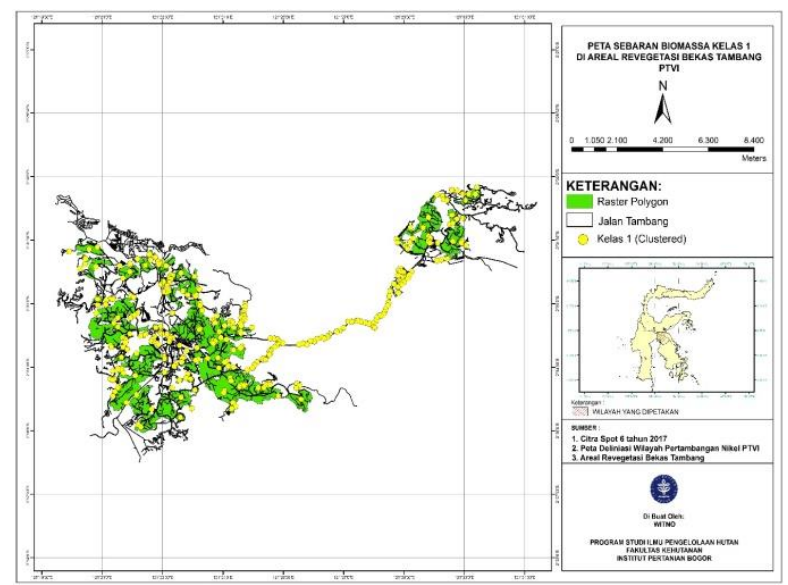

Gambar 2. Pola sebaran spasial biomassa K1 (Clustered) 


\section{Sebaran Spasial Biomassa K2}

Sebaran spasial biomassa K2 memiliki kandungan biomassa 58.88 sampai 117.75 ton/ha (Tabel 1). K2 memiliki pola mengelompok (Clustered) dengan nilai NNI sebesar $0.48<1$ dan nilai Z-score sebesar $14.63<1.96$. Hasil overlay dengan kelas umur tanaman revegetasi menunjukkan sebaran biomassa dominan pada kelas umur 2003 sampai tahun 2011. Dengan jenis tanaman revegetasi yang tumbuh diantaranya Sengon Buto (Enterolobium cyclocarpum), Uru (Elmerrillia pubescens Dandy), Akasia (Acacia mangium) dan Nyatoh (Palquim sp). Luas areal sebaran spasial biomassa untuk K2 yaitu 1070.76 ha. Dengan kondisi vegetasi tumbuhan bawah pada sampel plot cukup subur dengan ditumbuhi oleh tanaman cover crop seperti pakis (Diplazium) dan rerumputan merambat. Kondisi tanaman revegetasi dan vegetasi tumbuhan bawa, di salah satu sampel plot yang diambil di lapangan diantaranya plot areal Debby pada tahun tanam 2003. Pola sebaran spasial biomassa K2 dapat dilihat pada Gambar 3.

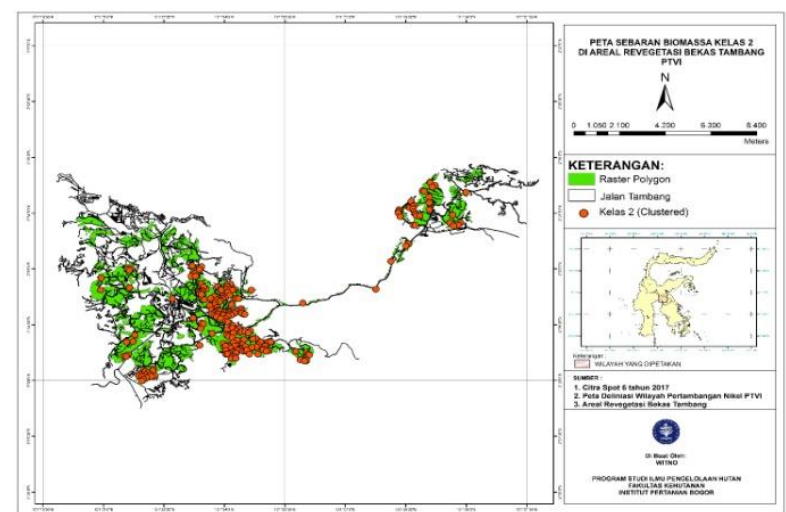

Gambar 3. Pola sebaran spasial biomassa K2 (Clustered)

\section{Sebaran Spasial Biomassa K3}

Sebaran spasial biomassa untuk K3 memiliki pola mengelompok dengan nilai NNI sebesar $0.74<1$ dan Z-Score sebesar -3.10< 1.96. Setelah dioverlay dengan umur tanam, menunjukkan sebaran biomassa berada pada rentang tahun tanam hampir sama dengan tahun tanam K2. K3 memiliki kandungan biomassa dengan rentang nilai antara 117.75 176.62 ton/ha (Tabel 1). Sebaran spasial biomassa K3 memiliki sebaran mengelompok dengan areal lebih kecil dibanding dengan K2. Luas areal sebaran spasial biomassa K3 yaitu 461.39 ha. Kondisi tanaman revegetasi untuk K3 dominan berada pada rentang umur tanaman 10 sampai 15 tahun.

Jenis dan umur tanaman revegetasi berkorelasi dengan laju produksi serasah, dekomposisi dan kandungan karbon tanah yang seiring waktu mampu menunjukkan keberhasilan revegetasi. Produksi serasah sangat berkorelasi dengan struktur tajuk. Selain itu, juga dipengaruhi oleh jenis tanaman yang berkorelasi dengan kandungan biomassa pada areal revegetasi bekas tambang nikel. Semakin banyak produksi serasah maka proses dekomposisi juga cepat yang bermanfaat pada kesuburan tanah. Kandungan biomassa lapangan pada K3 lebih dominan di peroleh di areal revegetasi dengan jenis tanaman Sengon (Enterolobium cyclocarpum), Uru, Akasia (Acacia mangium), Nyatoh (Palquim sp) dan Johar ( Senna siamea). Pola sebaran spasial biomassa K3 dapat dilihat pada Gambar 4.

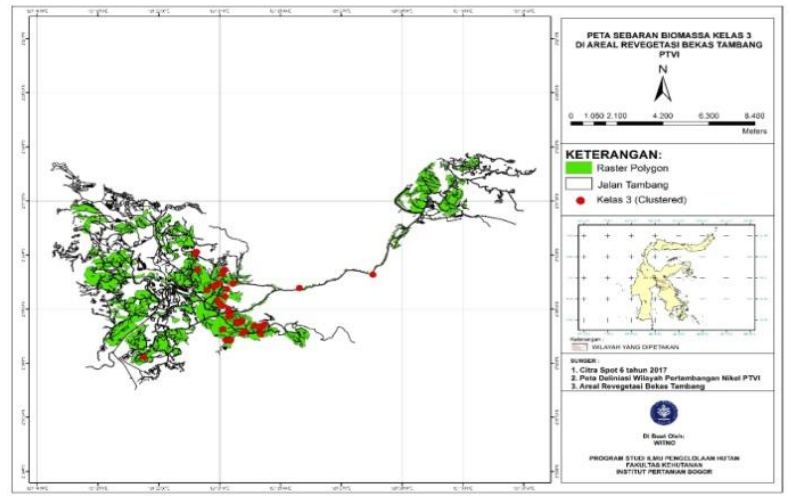

Gambar 4. Pola sebaran spasial biomassa K3 (Clustered)

\section{Sebaran Spasial Biomassa K4}

Sebaran spasial biomassa K4 memiliki pola menyebar (Dispersed) dengan nilai NNI sebesar $7.01>1$ dan Z-score sebesar 19.92 
>1.96. Berdasarkan nilai NNI dan Z-score menyimpulkan bahwa K4 dikategorikan dalam pola menyebar. Pada Gambar 5 menunjukkan sebaran biomassa yang lebih kecil atau areal yang lebih sedikit dibandingkan $\mathrm{K} 1, \mathrm{~K} 2$ dan $\mathrm{K} 3$. Luas areal sebaran spasial biomassa untuk K4 yaitu 153.60 ha. Dengan kandungan biomassa pada K4 sebesar 176.62 sampai 235.50 ton/ha (Tabel 1). Hal yang baru ditemukan, karena berdasarkan kandungan biomassa yang memiliki pola sebaran spasial yang menyebar. Masih dalam Rani (2003), menjelaskan bahwa pola sebaran spasial yang menyebar dari individu-individu populasi suatu spesies dalam suatu habitat menunjukkan bahwa terdapat keseragaman (homogenity) dalam lingkungan dan atau pola tingkah laku yang tidak selektif.

Dalam hal ini, sebaran spasial biomassa secara menyebar menunjukkan bahwa kandungan biomassa dipengaruhi oleh kondisi atau populasi tanaman revegetasi yang seragam pada satu areal tertentu. Seperti dipengaruhi oleh tingkat kesuburan atau jenis tanaman revegetasi. Pada penelitian ini, didapatkan sebaran biomassa pada beberapa areal tertentu saja. Dengan jarak antara areal satu dengan yang lainnya sangat berjauhan. Seperti hasil dari penelitian ini, berdasarkan luasan didapatkan sebaran biomassa berada pada tahun tanam 2002 dan 2004. Kondisi vegetasi pada $\mathrm{K} 4$, dengan lantai hutan tertutup rapat dengan tanaman cover crop seperti Ficus, Macaranga, Vitex, Krinyol dan Dillenia. Selain tanaman cover crop juga ditumbuhi oleh jenis tanaman liana, rumput tali-tali, dan Pakis. Pada beberapa plot juga terdapat tanaman lokal di antaranya Bitti (Vitex cofassus), Buri (Weinnamia blumei) dan Dengen (Dillenia serrata). Sedangkan jenis tanaman revegetasi yaitu Sengon (Enterolobium cyclocarpum).

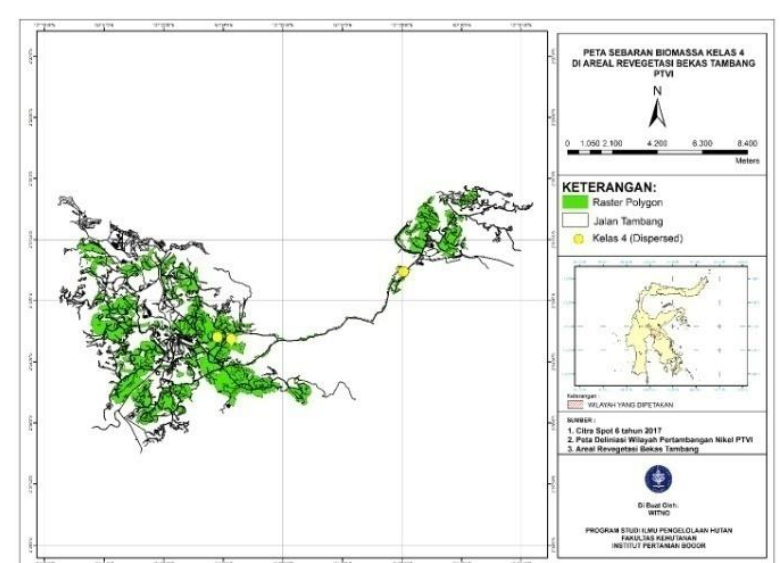

Gambar 5. Pola sebaran spasial biomassa K4 (Dispered)

Pengetahuan tentang pola sebaran spasial biomassa di areal revegetasi bekas tambang dapat dimanfaatkan sebagai bahan evaluasi pengelolaan tanaman revegetasi. Upaya untuk mengembalikan kondisi hutan seperti semula menjadi tanggung jawab besar pihak pengelolah areal revegetasi bekas tambang. Membutuhkan banyak informasi sebagai bahan evaluasi perencanaan pengelolaan tanaman revegetasi. Khususnya dalam melakukan monitoring mampu mengevisienkan waktu dan tenaga. Informasi dari penelitian ini dapat menjadi informasi sebagai bahan evaluasi. Informasi sebaran spasial biomassa di areal revegetasi bekas tambang masih jarang di lakukan sebagai salah satu indikator produktivitas hutan. Selain itu, berdasarkan Peraturan Pemerintah nomor 78 Tahun 2010 tentang reklamasi dan pascatambang. Bahwa prinsip perlindungan dan pengelolaan lingkungan hidup pertambangan wajib memperhatikan perlindungan terhadap kualitas air permukaan, air tanah, air laut dan kuantitas air tanah.

Sebaran spasial biomassa di areal revegetasi bekas tambang menunjukkan pola sebaran spasial biomassa dominan di areal yang berdekatan dengan sumber air. Khususnya untuk K2 dan K3 dominan mengelompok mendekati sumber air. Hal ini bisa menandakan bahwa kondisi ekologi 
Volume 1 Nomor 2 Des 2019:1-9

sangat berpengaruh dalam terbentuknya pola mengelompok biomassa. Poedjirahajoe et al. (2017) dan Purwanto et al. (2014), mendapatkan penelitian yang dilakukan di areal hutan mangrove dengan pola sebaran spasial mengelompok.

\section{KESIMPULAN}

Hasil penelitian ini menyimpulkan bahwa pola sebaran spasial biomassa di areal revegetasi bekas tambang nikel PTVI ada dua yaitu pola mengelompok (Clustered) pada biomassa $\mathrm{K} 1, \mathrm{~K} 2$, K3 dan pola menyebar (Dispersed) pada biomassa K4.

\section{DAFTAR PUSTAKA}

Claassen S, Rensburg, PJJV, Maboeta MS,

Rensburg LV. 2008. Soil microbial commu nity function and structure in a post-mining chronosequence. Water Air Soil Pollution (194): 315-329.

Condit R, Ashton PS, Baker P, Bunyavejchewin S, Gunatilleke S, Gunatilleke N, \& Lee HS. 2000. Spatial patterns in the distribution of tropical tree species. Science, 288(5470), 14141418.

Hilmi E.2003. Model Penduga Kandungan Karbon Pada Pohon Kelompok Jenis Rhizopora spp. dan Bruguiera spp. Dalam Tegakan Hutan Mangrove (Studi Kasus di Indragiri Hilir Riau)[Tesis]. Bogor (ID): Institut Pertanian Bogor.

Krebs CJ. 1989. Ecological Methodology. Harper Collins Publisher, Inc. New York.

Krebs CJ. 2014. Ecological Methodology. Vancouver (CA): University of British Columbia.
Lomolino MV, Riddle BR, Whittaker RJ, Brown JH. 2010. Biogeography. United States (US). Sinauer Associates, Inc.

Ludwig JA. dan JF. Reynold. 1988. Stasistical

Ecology. A Primary On Methods and Computing. Canada (CA): John Wiley \& Sons, Inc.

Poedjirahajoe E. Marsono D, Wardhani FK. 2017. Penggunaan principal analysis dalam distribusi spasial vegetasi mangrove di pantai utara pemalang. Jurnal Ilmu Kehutanan. Vol 2(1):29-42.

Purwanto AD, Asriningrum W, Winarso G, Parwati E. 2014. Analisis Sebaran dan Kerapatan Mangrove Menggunakan Citra Landsat 8 di Segara Anakan Cilacap. Seminar Nasional Penginderaan Jauh 2014. 232-241

Rani C. 2003. Metode pengukuran dan analisis pola spasial (dispersi) organisme bentik. Jurnal Protein (19):1351-1368

Witno, Puspaningsih N, \& Kuncahyo B. 2018. Biomass Estimation Model in Revegetation Area of Nickel PostMining. Media Konservasi, 23(3), 293302. 